\title{
Micromorphological assessment of bone tissue remodeling in various hip degeneration conditions
}

\author{
Mirosław Kulej $]^{1, A, C, D}$, Szymon Łukasz Dragan, ${ }^{1, B-D}$, Jan Kuryszko ${ }^{2, B-D}$, \\ Piotr Kuropka ${ }^{2, B, C}$, Wojciech Widuchowski, ${ }^{3, E}$, Szymon Feliks Dragan ${ }^{1, A, E, F}$ \\ ${ }^{1}$ Clinic of Orthopedics and Traumatology, Department of Regenerative and Restoration Medicine in Orthopedics, Wroclaw Medical University, Poland \\ ${ }^{2}$ Department of Animals Biostructure and Physiology, Faculty of Veterinary Medicine, Wrocław University of Environmental and Life Sciences, Poland \\ ${ }^{3}$ District Hospital of Orthopedics and Trauma Surgery, Department of the Knee Surgery, Arthroscopy and Sports Traumatology, Piekary Śląskie, Poland \\ A - research concept and design; $\mathrm{B}$ - collection and/or assembly of data; $\mathrm{C}$ - data analysis and interpretation; \\ $\mathrm{D}$ - writing the article; $\mathrm{E}$ - critical revision of the article; $\mathrm{F}$ - final approval of the article
}

\section{Address for correspondence \\ Mirosław Kulej}

E-mail: miroslaw.kulej@umed.wroc.pl

Funding sources

None declared

Conflict of interest

None declared

Received on May 2, 2018

Reviewed on December 18, 2018

Accepted on September 1, 2019

Published online on February 4, 2020

Cite as

Kulej M, Dragan SŁ, Kuryszko J, Kuropka P, Widuchowski W, Dragan SF. Micromorphological assessment of bone tissue remodeling in various hip degeneration conditions Adv Clin Exp Med. 2020;29(1):51-61. doi:10.17219/ acem/112059

DOI

10.17219/acem/112059

Copyright

Copyright by Author(s)

This is an article distributed under the terms of the

Creative Commons Attribution 3.0 Unported (CC BY 3.0)

(https://creativecommons.org/licenses/by/3.0/)

\begin{abstract}
Background. The reorganization of bone tissue is closely associated with its metabolism and changes in its internal structure. Metabolism of the bone, which results from the simultaneous processes of resorption and formation of new bone tissue, may depend on the presence and type of arthritis.

Objectives. The objective of the study was to assess, based on the morphological features and mineral composition of bone tissue, changes in the femoral head in various types of hip joint degeneration.

Material and methods. The study group consisted of 21 patients surgically treated for hip joint degeneration. They included 17 women, aged 30-70 years (mean age 52.5 years), and 4 men, aged 38-51 (mean age 48.5 years). The assessment of the morphological condition of the bone and the mineral composition of bone tissue took into account quantitative and qualitative relationships among the mineral components and bone matrix. The structure of spongious bone tissue was analyzed in histological studies, with special attention paid to osteogenesis and osteoclastic processes and the advancement of degeneration.

Results. Three main types of degenerative changes in bone tissue of the examined femoral head were recognized: osteoporosis with a prevalence of coarse-fiber bone tissue and decreased osteogenic activity; osteolysis with few osteogenesis centers; and intensified reorganization of bone tissue. In more than half of the examined samples, coarse-fiber bone tissue was replaced by newly formed bone tissue. We observed bone resorption and osteogenesis, which indicate normal homeostasis of the bone tissue. Uneven saturation of spongious bone with mineral components was found. The content of organic and inorganic bone components measured with $C a: P$ and $C: C a+P$ ratios had similar values in all types of changes. Only the bone with intense osteolysis contained a smaller quantity of carbon (4.96-8.13\%).
\end{abstract}

Conclusions. Our observations indicate an intense adaptive reorganization of bone tissue depending on external and internal factors, including biomechanical condition.

Key words: bone, remodeling, micromorphometry, hip joint degeneration 


\section{Introduction}

Bone tissue is a specialized connective tissue which plays a mechanical and metabolic role; its characteristic feature is constant reorganization and adaptation of its structure to external factors. ${ }^{1}$ Changes in internal structure and metabolism of bone which result from the simultaneous processes of resorption and formation of new bone tissue have been described by Frost ${ }^{2}$ and termed the adaptive restructuration of bone. Contrary to intra-osseous changes, Frost ${ }^{3}$ called shaping of external structure of the bone modelling. According to Frost's theory, tensions arising in bone tissue under the effect of load cause microcracks of the trabeculae, which in turn stimulates the processes of bone reorganization. ${ }^{4}$

There are many theories on the effect of electric potential and inter-cellular liquid on bone tissue reorganization, ${ }^{5,6}$ though most authors believe that the main role in the process is played by mechanical factors, such as form distortion, the energy of form distortion and the density or index of form distortion of the bone..$^{3,7-13}$ The reorganization of bone tissue is closely associated with bone metabolism. ${ }^{14}$ The mechanical properties of bone are determined by the quantity of organic and inorganic components and the structure of bone trabeculae, which are composed of collagen fibers and the hydroxyapatite crystals deposited on them. ${ }^{15,16}$ Experimental studies on the mechanical resistance of bone tissue indicate that the Young elasticity module for a hydroxyapatite crystal is $114 \mathrm{GPa}$ and is nearly 10 times higher than the Young axial module of a collagen molecule, which is $1.41 \mathrm{GPa},{ }^{17-19}$ thus the quantity and proper structure of hydroxyapatite has a decisive effect on the mechanical resistance of the bone. The organic components (organic matrix) of bone tissue constitute $34.9-41 \%$ of the bone mass, mineral components approx. $50 \%$, water $15.5-27 \%$, and volatile inorganic components $4.2-4.6 \%$. The bone matrix consists of approx. 90\% collagen; the remaining $10 \%$ is non-collagen proteins. About $50 \%$ of the mineral substances form a part of hydroxyapatite $\mathrm{Ca} 10(\mathrm{PO} 4) 6(\mathrm{OH}) 2$. In its combusted form, the mineral substances constitute $33.9-39.9 \%$ of the bone mass. ${ }^{20}$

The proportions and quantitative changes of organic (collagen) and mineral (hydroxyapatite) components are described using the ratio of carbon $(C)$ to the combined quantity of calcium and phosphorus $(\mathrm{Ca}+\mathrm{P})$. Normal proportions of calcium and phosphorus in an ideally built hydroxyapatite crystal in vitro are expressed using a molar calcium-to-phosphorus ratio $(\mathrm{Ca} / \mathrm{P})$ of $1.67: 1 .{ }^{21} \mathrm{Ex}-$ perimental studies on hydroxyapatite structure revealed that in vivo other elements - especially heavy metal ions - could replace calcium ions in hydroxyapatite crystals, change their chemical composition and structure, and lead to a deterioration of their mechanical properties. Considering the effect of habitat factors and diet, the molar calcium-to-phosphorus ratio $(\mathrm{Ca}: \mathrm{P})$ in the hydroxyapatite crystals of human bones under normal conditions was determined to be $2: 1 .^{22,23}$ There are no corresponding estimates for a normal carbon-to-combined calcium and phosphorus $(\mathrm{C}: \mathrm{Ca}+\mathrm{P})$ ratio. It is believed that disturbances in the quantity of mineral components, especially hydroxyapatite, affect the quality of bone tissue.

This study was aimed at determining, on the basis of morphological state and the mineral composition of bone tissue, the changes taking place in the femoral head in various types of hip joint degeneration.

\section{Material and methods}

Samples from 21 patients surgically treated for hip joint degeneration at the Department and Clinic of Orthopedic and Traumatological Surgery in the Faculty of Postgraduate Medical Training of Wroclaw Medical University, Poland, were used in the study. The study group consisted of 17 women aged $30-70$ years (mean 52.5 years) and 4 men aged 38-51 (mean 48.5) (Table 1).

Secondary reasons for hip joint degeneration were diag-

Table 1. Number, sex and age (range and mean) of patients in the study population

\begin{tabular}{|l|c|c|c|}
\hline \multicolumn{1}{|c|}{ Variable } & $\begin{array}{c}\text { Number } \\
\text { of patients }\end{array}$ & Age range & Mean age \\
\hline Whole population & 21 & $30-70$ & 51 \\
\hline Women & 17 & $30-70$ & 52.5 \\
\hline Men & 4 & $38-51$ & 48.5 \\
\hline
\end{tabular}

nosed in 13 patients (61.9\%) and primary reasons in 8 patients (38.1\%). Degeneration following inborn hip dysplasia developed in 5 patients (23.8\%), stemming from rheumatoid arthritis in 7 patients $(33.3 \%)$ and as a result of injury in 1 patient (4.8\%).

The assessment of morphological condition and the mineral composition of bone tissue, considering the quantitative and qualitative relationships between mineral components and bone matrix for various types of hip degeneration, was based on the femoral heads extracted from 21 patients during hip replacement operations. The histological examination and mineral composition analysis were carried out at the Department of Histology and Embryology, Chair of Anatomy and Histology of the Faculty of Veterinary Medicine at the Natural History University in Wrocław.

Depending on the type of morphological changes observed in histological examination, the samples were divided into 3 groups and a mineralographic analysis was carried out. Statistical analysis of the results of the mineralographic studies was then performed using the data on the morphological changes observed in the tissue during histological examination. 


\section{Assessment of histological structure and mineral composition of the bone tissue}

The surgically removed femoral heads were cut along the diameter and samples of spongious bone tissue were taken from the central and peripheral parts (Fig. 1). The material for histological examination was fixed in $4 \%$ buffered formalin. After decalcification, the bone block was dehydrated and embedded in paraffin. The material for electron microscope studies was fixed in glutaraldehyde on phosphate buffer $0.1 \mathrm{~N}$, dried in critical point and gold-coated. Sections with $10 \mu \mathrm{m}$ in thickness were stained with hematoxylin and eosin (H\&E), according to van Gieson and Schmorl.

The structure of spongious bone tissue was examined histologically, with special attention being paid

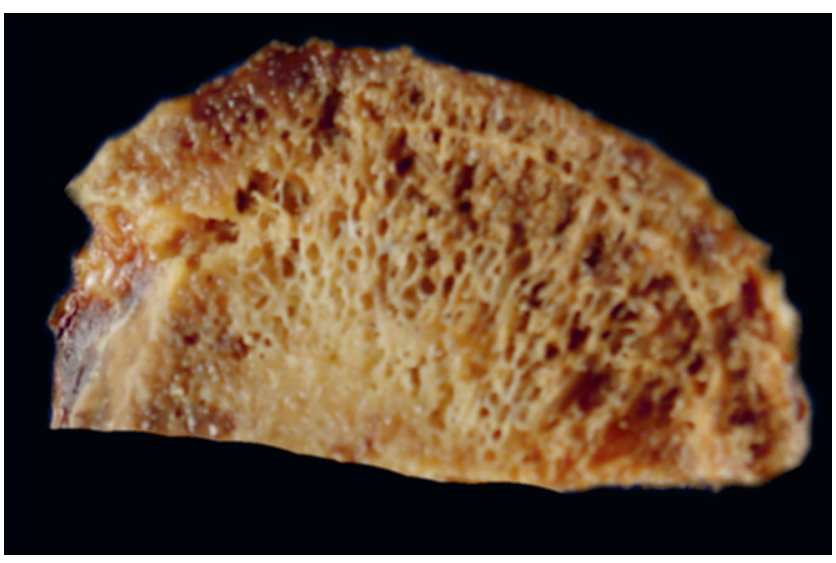

Fig. 1. Cross-section of a femoral head from which samples for histological and mineralogical analysis were taken to osteogenic and osteoclastic processes and the advancement of degenerative changes. Electron microscope analysis was conducted with a LEO 435 Scanning Electron Microscope (SEM) with a ROENTEC Roentgen microprobe (Leo/Zeiss, Jena, Germany). Surface analysis of the mineral composition was carried out at constant magnification of $\times 500$ and an accelerating voltage of $20 \mathrm{keV}$.

\section{Results}

\section{Histological examination}

Three types of changes were observed during histological examination of the femoral heads which were surgically removed from the patients:

1. osteoporosis with immature coarse-fiber bone tissue and low osteogenic activity;

2. osteolysis with osteogenesis centers; and

3. intense bone reorganization.

Osteoporosis with immature coarse-fiber bone tissue and low osteogenic activity, of varying intensity, were observed in the femoral heads of 6 patients.

The histological slides of this group of patients showed numerous areas occupied by fibrous bone tissue with blood vessels and fat cells within it. The trabeculae were thinner than in other groups of patients; on their surfaces, osteoclasts were observed sporadically and, more often, osteoblasts (Fig. 2A). In extensive areas, the trabeculae were covered by bone surface cells, which indicates low metabolic activity of bone tissue in such areas (Fig. 2B). Some slides showed degenerative changes within the cartilage, with numerous lesions of joint cartilage (Fig. 3).

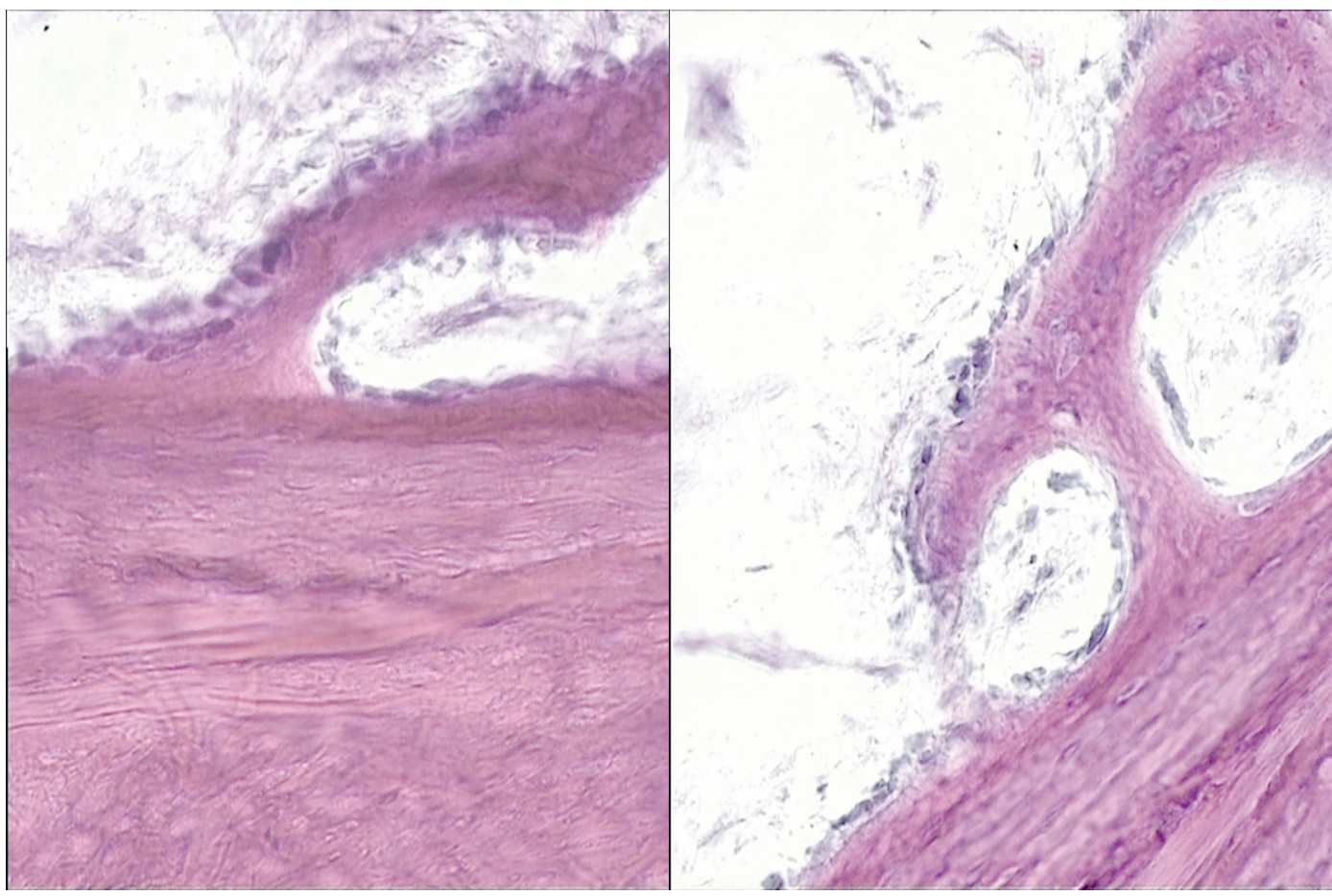

Fig. 2. A. Osteoblasts on the surface of bone trabeculae. H\&E staining, $\times 400$ magnification. B. Trabeculae without cells on the surface or between them; visible fat cells and reticulate tissue; center of trabeculae built of coarse-fiber bone tissue covered by 1 lamella of secondary bone with few osteocytes. H\&E staining, $\times 100$ magnification 


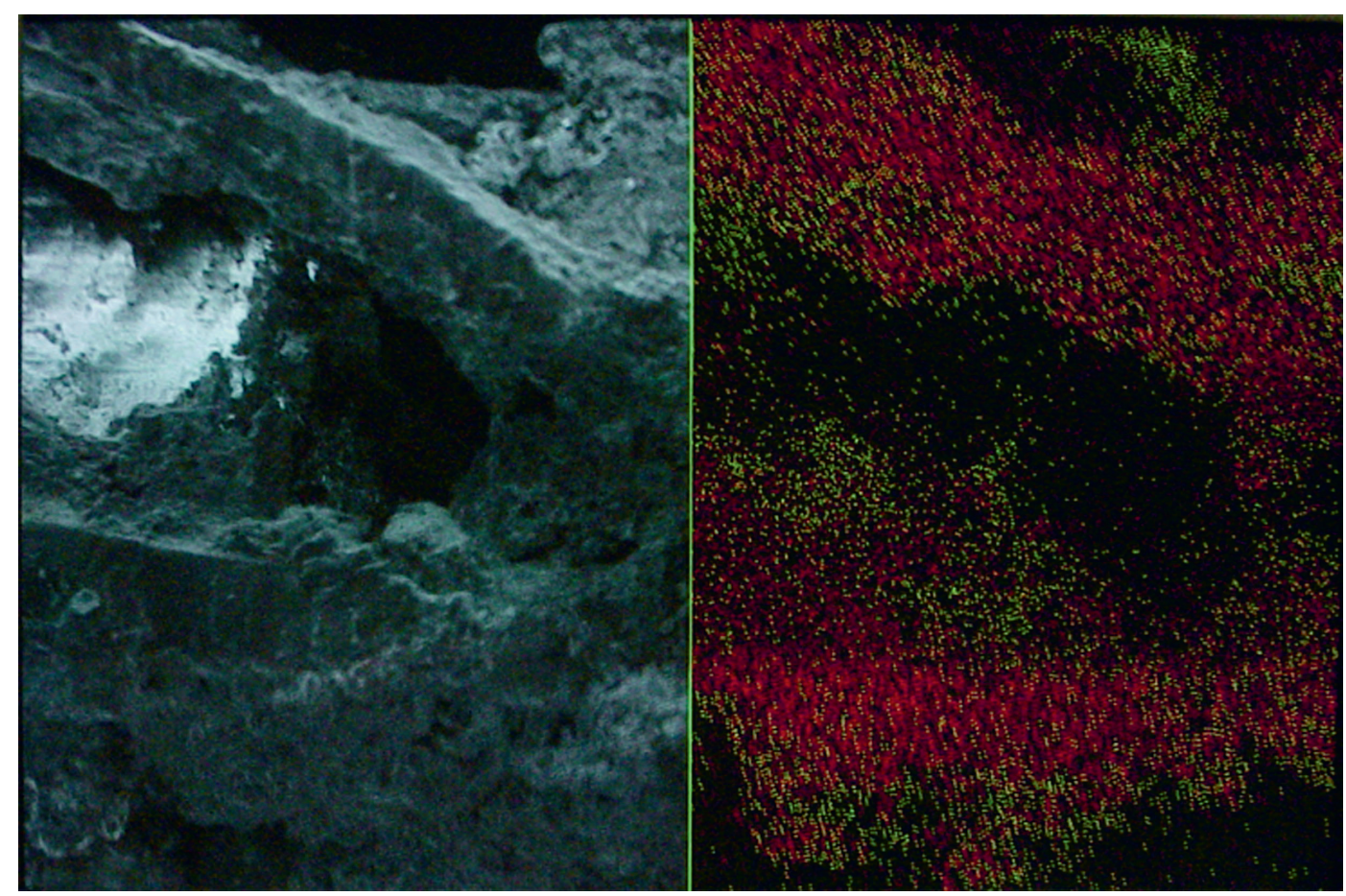

Fig. 3. Elements distribution in the bone beneath the articular surface of a femoral head surface

Red - carbon;

green - calcium;

yellow - phosphorus SEM, $\times 1000$.

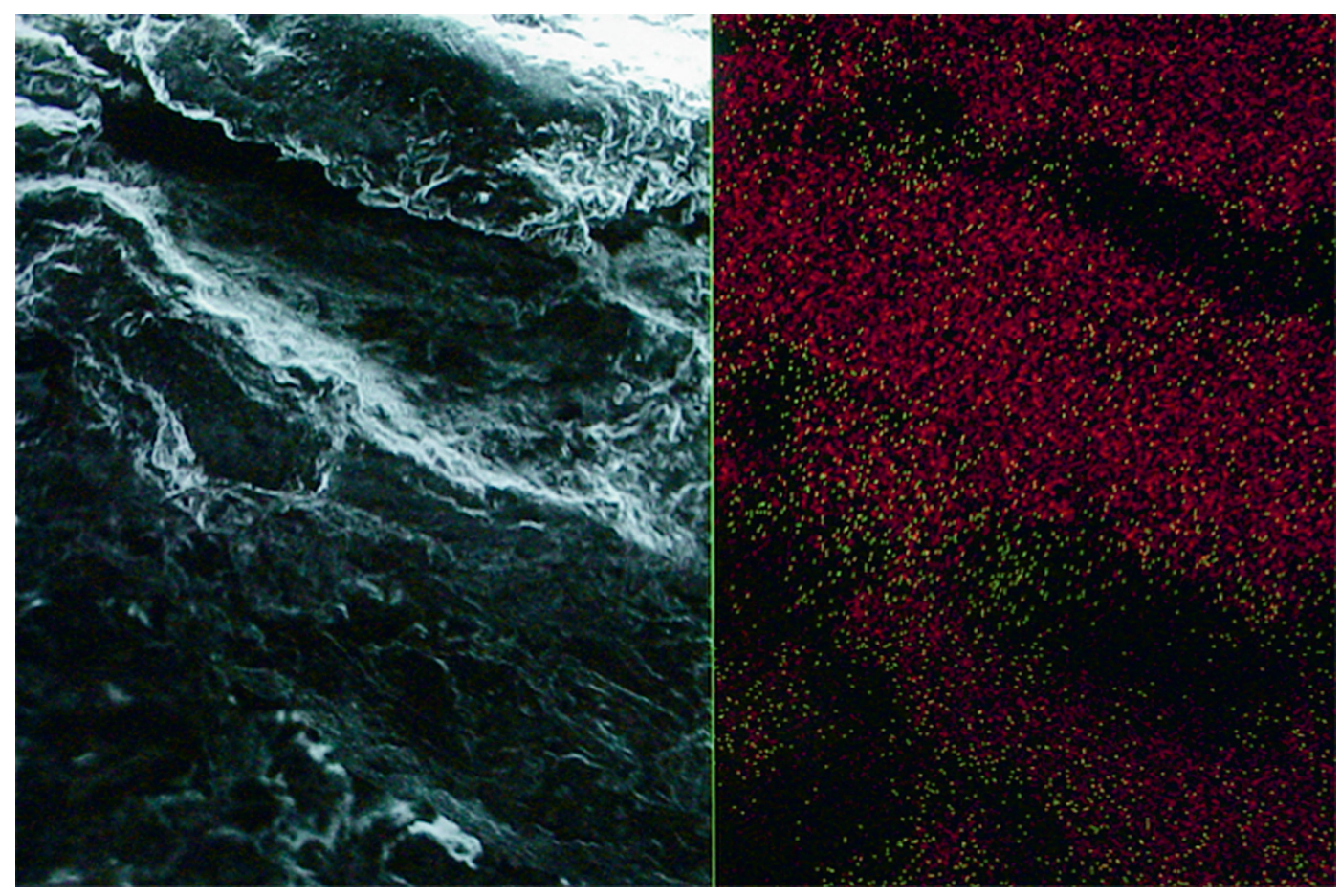

Fig. 4. Elements distribution in area near "cyst-like changes". On the surface of the trabecula there are no active cells of bone tissue. In the center, there are fibers of connective tissue with blood vessels.

Red - carbon; green - calcium yellow - phosphorus SEM, $\times 1000$.

No activity of osteogenic cells or osteoclasts was observed in the subcartilaginous part and within the spongious bone. Fibroblasts synthesizing collagen fibers were visible in areas below the joint cartilage. In 1 case, among irregularly arranged trabeculae, numerous fibrous structures were present; they were built of collagen fibers with fat cells, with numerous fibrocytes and fibroblasts in between (Fig. 4).

Osteolysis with few osteogenesis centers, with varying intensity, was observed in 4 patients. In areas located close to the articulation surface, extensive osteolysis was observed, aided by neutrophil granulocytes; in its center, numerous fibroblasts, fat cells and developing blood vessels were found. Outside the osteolysis area, the multiplication of connective tissue cells and intensified angiogenesis were observed. In places remote from the osteolysis areas, few centers of repair osteogenesis were noted (Fig. 5A).

Extensive "cyst-like changes" were observed within the trabeculae. Such areas inside were filled by numerous cells of fibroblastic lineage synthesizing connective tissue 


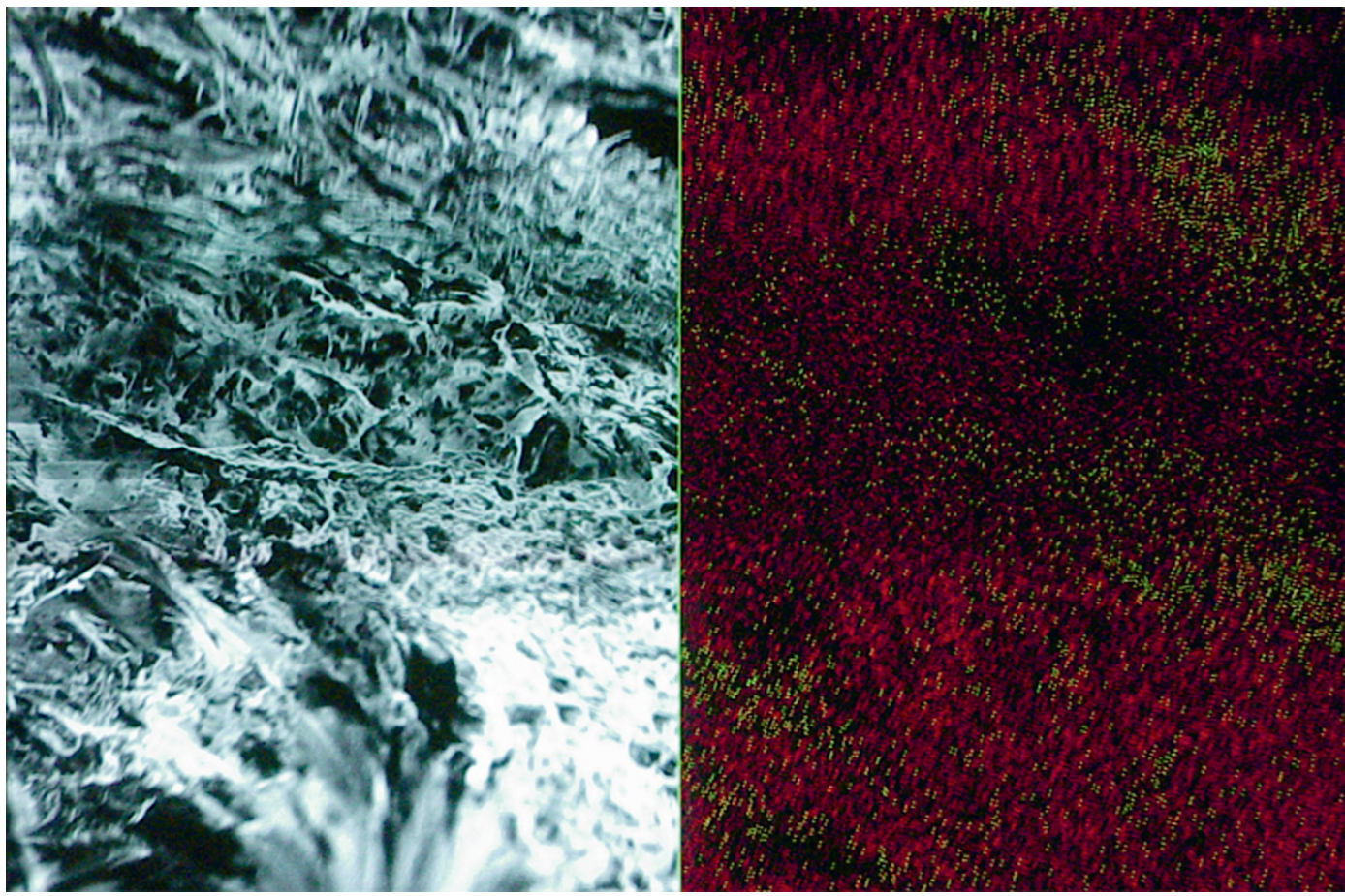

Fig. 5. Elements

distribution in area near

"cyst-like changes".

In the center, there are numerous collagen fibers of connective tissue.

Red - carbon;

green - calcium;

yellow - phosphorus SEM,

$\times 1000$
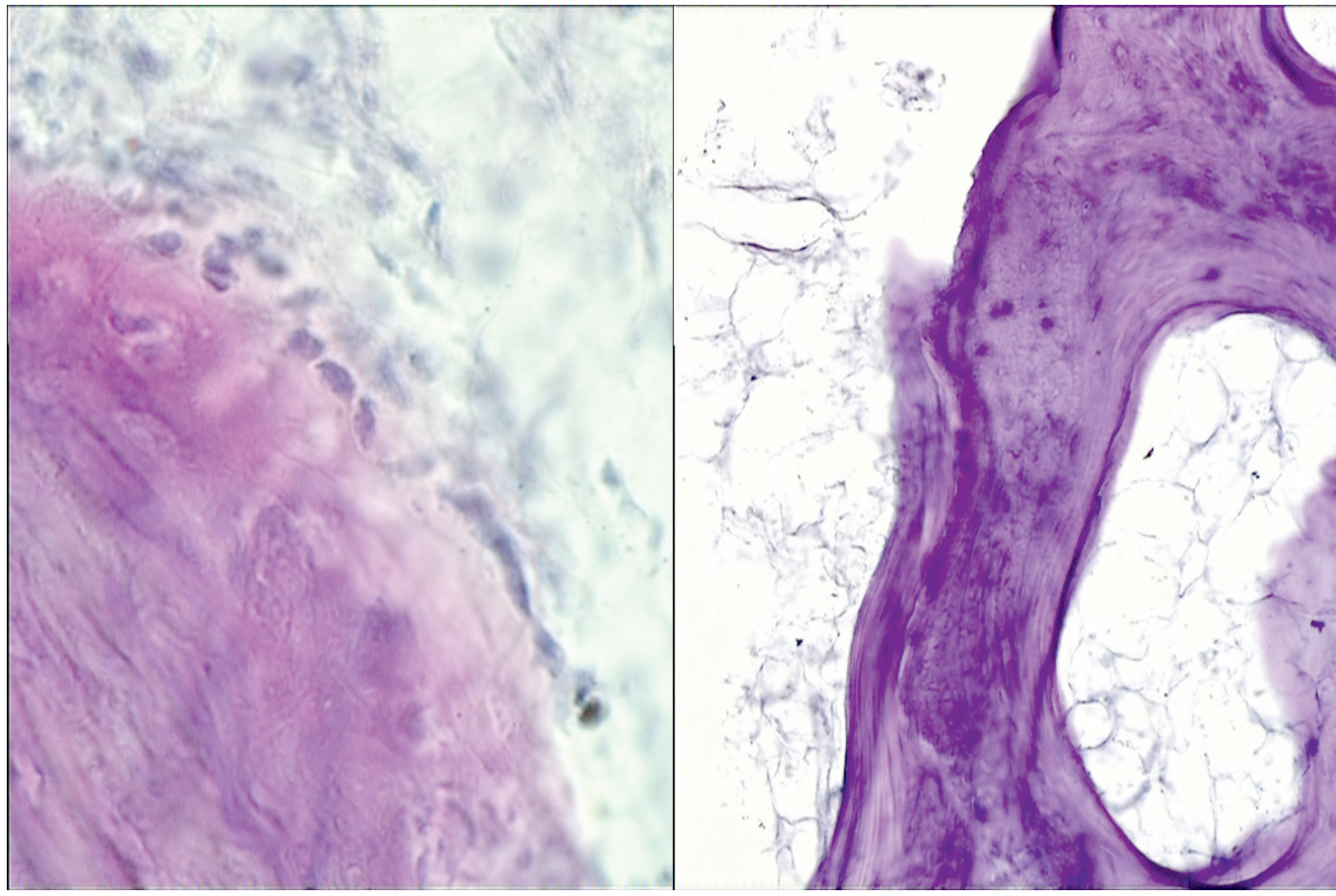

Fig. 6. A. Coarse-fiber bone tissue resorbed by osteoclasts and mononucleate cells (left). H\&E staining, $\times 200$ magnification. B. Bone trabecula; no cells are on the surface or between the trabeculae. Fat cells and reticulate tissue are visible. H\&E staining, $\times 100$ magnification

fibers which were randomly arranged (Fig. 5B). Outside these areas, osteoclasts, mononuclear macrophages and cells of the lymphatic-granulocytic system were visible (Fig. 6A). In the remaining areas, the trabeculae showed an irregular course and abundant fibrous connective tissue between them. Histological slides from 2 patients showed trabeculae which were much thinner than those of the remaining patients from this group, and small quantities of connective tissue and fat cells were observed between them (Fig. 6B).
Degeneration of joint cartilage was also observed, with numerous lesions and degenerating chondrocytes (Fig. 7). Intense bone reorganization, with varied intensity, was observed in 14 patients. The joint cartilage showed large surface lesions and a considerable degeneration of the chondrocytes. On some slides near joint cartilage, the proliferation of fibroblastic lineage cells was also observed, appearing as fibrous areas below the joint cartilage (Fig. 8).

Differentiated areas of coarse-fiber bone tissue predominated in the subcartilage tissue (Fig. 9). Areas of drastic 


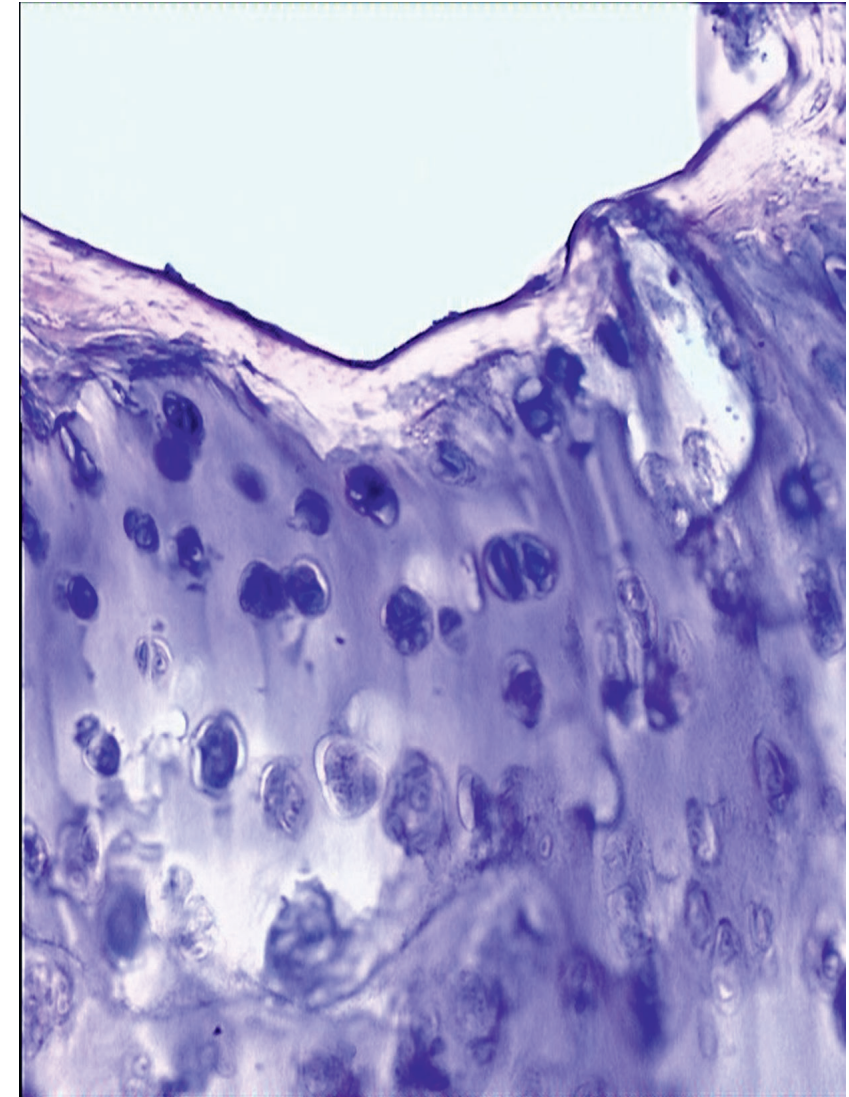

Fig. 7. A. Abnormal joint cartilage; visible stratification (right) of cartilage located directly above a biologically inactive area of bone tissue. H\&E staining, $\times 100$ magnification. B. Degenerating joint cartilage. The visible changes within the chondrocytes indicate progressing degenerative changes. H\&E staining, $\times 200$ magnification

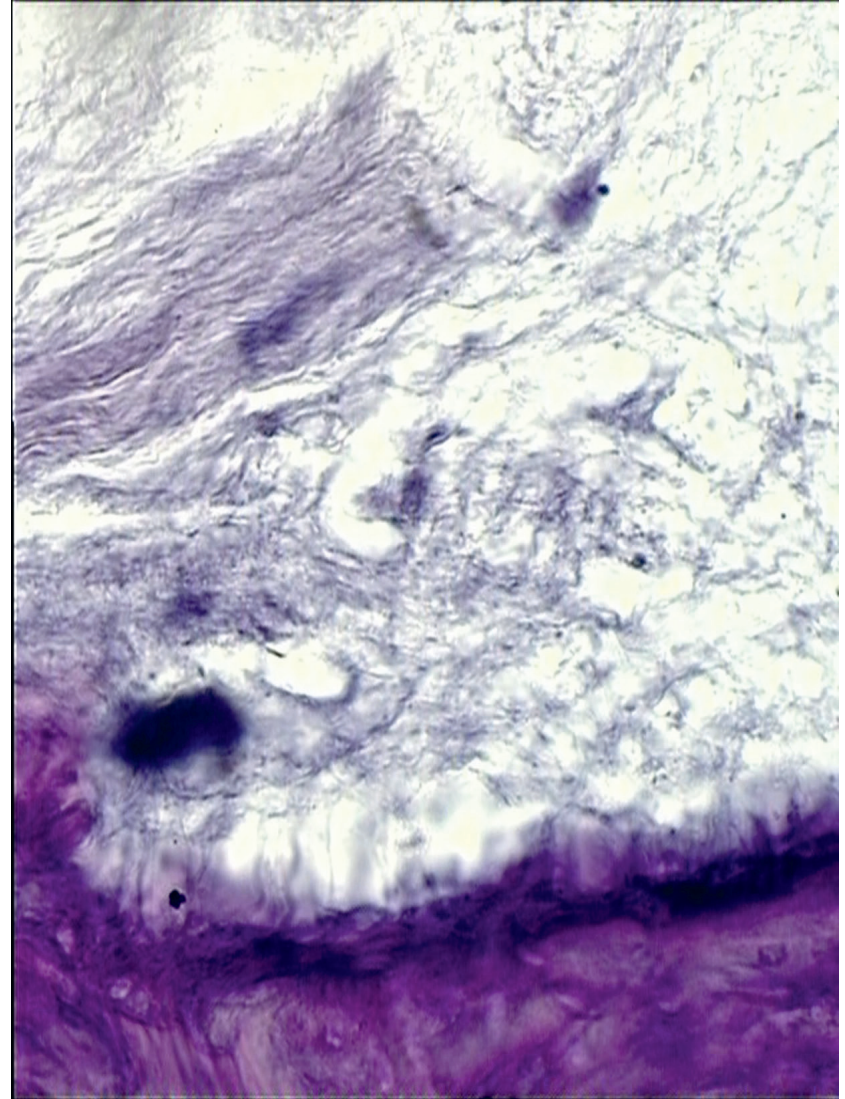

Fig. 8. Greatly reduced articular surface of the femoral head. Few isogenic groups containing degenerating chondrocytes. Cartilage on the side opposite of the articular surface shows structural disturbances manifested as irregular invaginations between the trabeculae. Articular surface is irregular, distinctly mechanically damaged. H\&E staining, ×200 magnification

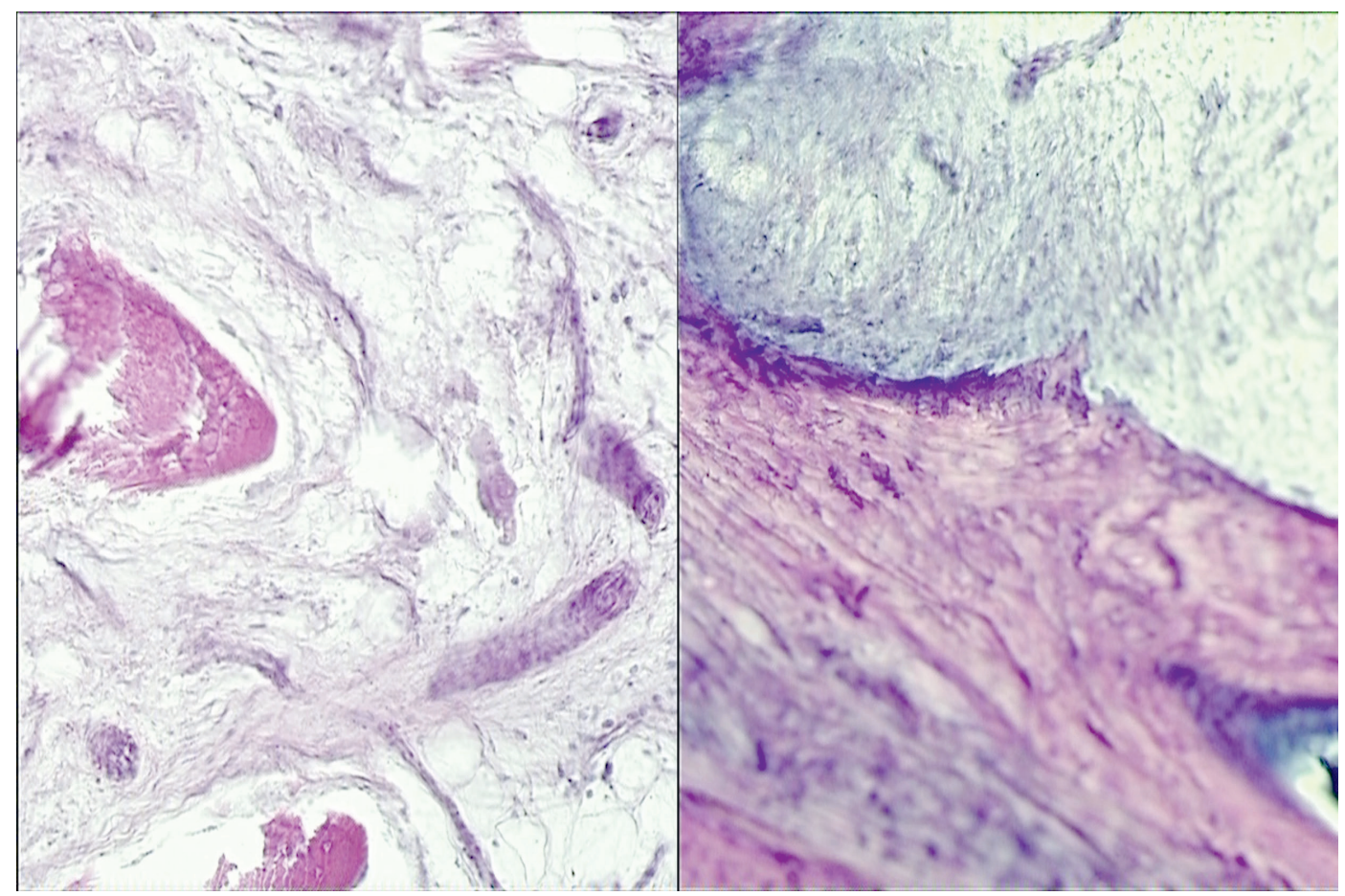

Fig. 9. A. Metabolically active bone; in the center, areas of osteolysis with osteoclasts; above, bone tissue with osteoblasts. H\&E staining, $\times 100$ magnification. B. Synthesis of bone tissue matrix (center); osteoblasts surrounding an island of coarse-fiber bone tissue are visible. H\&E staining, $\times 200$ magnification 


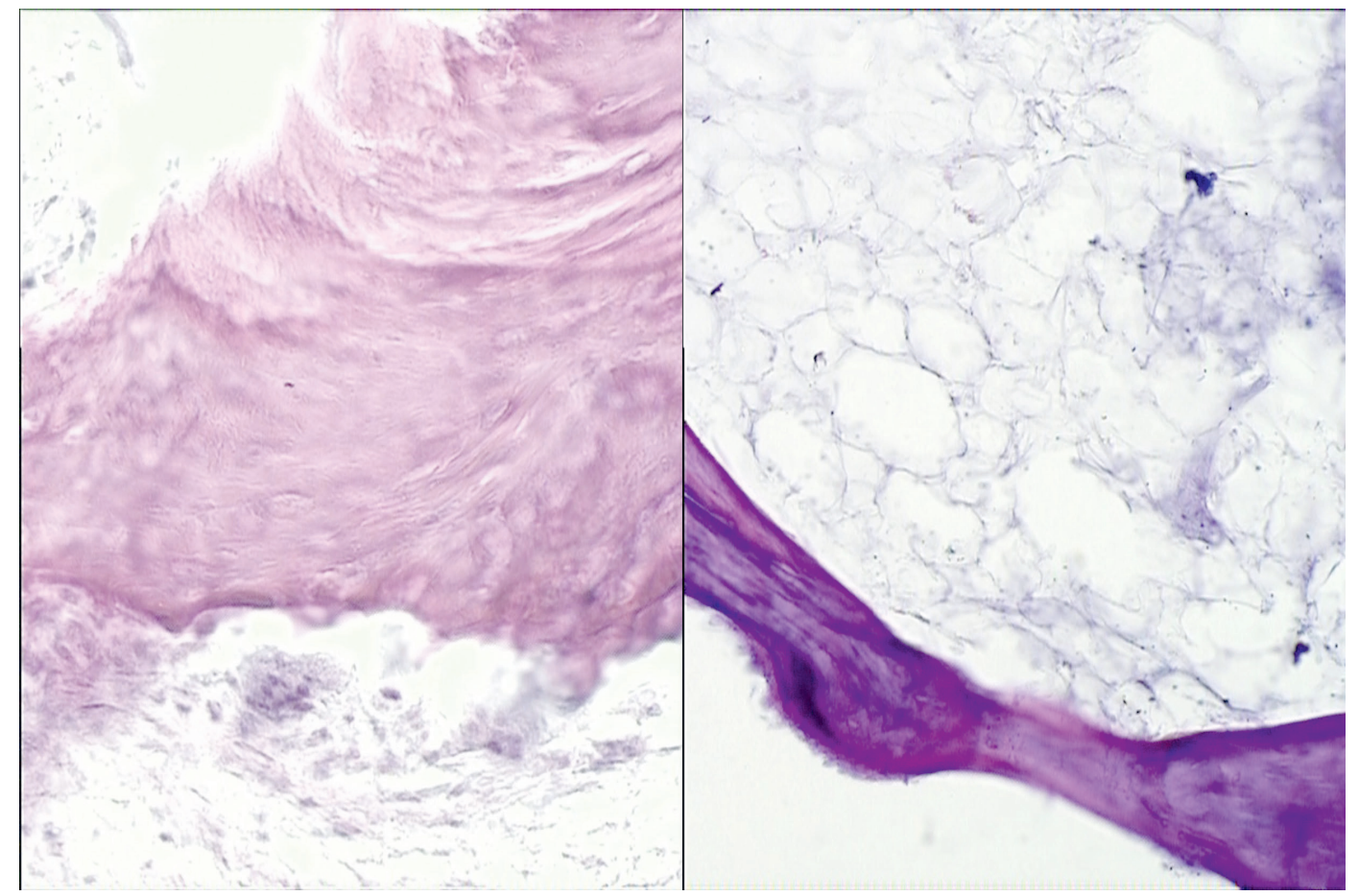

Fig. 10. A. Numerous osteoblasts on the surface of the trabeculae. H\&E staining, $\times 400$ magnification. B. Numerous osteoblasts on the surface of the trabeculae. H\&E staining, $\times 200$ magnification reorganization of bone tissue were visible in the central part of the femoral head. Areas of coarse-fiber bone tissue were replaced by new bone tissue, hence the presence of osteoclasts and osteoblasts on their surface (Fig. 10).

\section{Results of mineral composition analysis}

The analysis of mineral composition of bone tissue included all samples from the patients. The data was then analyzed within each of the 3 groups distinguished based on histological changes.

Among the whole study group, the carbon content was $52.04 \% \pm 9.78 \%$, calcium $10.21 \% \pm 2.69 \%$ and phosphorus $5.18 \% \pm 1.98 \%$. The calcium-to-phosphorus ratio was $2.05 \pm 0.89$ and the ratio of carbon to calcium plus phosphorus was $4.56 \pm 1.23$ (Table 2).

For the osteoporosis group, the electron microscope examination revealed an uneven distribution of elements on the sample surface (Fig. 11). In all samples, the calciumto-phosphorus ratio ( $\mathrm{Ca}: \mathrm{P})$ was normal and amounted to $2.16 \pm 0.78$. The ratio of carbon to calcium plus phosphorus $(\mathrm{C}: \mathrm{Ca}+\mathrm{P})$ was $6.01 \pm 0.12$, but in 6 cases it was low and in 1 case very high (21.33). The very low calcium and phosphorus content was likely the effect of a very low quantity of hydroxyapatite.

The distribution of the mean content of elements in the examined samples, determined using mineralographic analysis, was typical for the whole set and amounted to $49.79 \% \pm 5.23 \%$ for carbon, $10.42 \% \pm 1.34 \%$ for calcium and $5.02 \% \pm 0.59 \%$ for phosphorus (Table 2 ). The $2^{\text {nd }}$ group of patients - with intensified osteolysis with few osteogenesis centers - showed an uneven distribution of elements in the bone with a mean carbon content of $44.83 \% \pm 8.45 \%$,
Table 2. Mean content of elements (\%), calcium-to-phosphorus ratio and carbon-to-calcium plus phosphorus ratio in bone tissue in the whole study population and by group according to histology

\begin{tabular}{|l|c|c|c|c|}
\multirow{2}{*}{ Element } & \multicolumn{4}{|c}{ Mean content of element per sample [\%] } \\
\cline { 2 - 5 } & $\begin{array}{c}\text { whole } \\
\text { population }\end{array}$ & group 1 & group 2 & group 3 \\
\hline $\mathrm{C}$ & 52.04 & 49.79 & 44.83 & 45.92 \\
\hline $\mathrm{O}$ & 30.89 & 33.28 & 36.89 & 30.19 \\
\hline $\mathrm{Na}$ & 0.44 & 0.36 & 1.18 & 0.51 \\
\hline $\mathrm{Mg}$ & 0.23 & 0.19 & 0.29 & 0.20 \\
\hline $\mathrm{P}$ & 5.18 & 5.02 & 5.34 & 4.42 \\
\hline $\mathrm{Cl}$ & 0.43 & 0.38 & 0.34 & 0.37 \\
\hline $\mathrm{Ca}$ & 10.21 & 10.42 & 9.99 & 8.87 \\
\hline $\mathrm{Fe}$ & 0.08 & 0.07 & 0.08 & 0.07 \\
\hline $\mathrm{K}$ & 0.34 & 0.19 & 0.47 & 0.27 \\
\hline $\mathrm{S}$ & 0.44 & 0.42 & 0.57 & 0.14 \\
\hline $\mathrm{Cu}$ & 0.24 & 0.03 & 0.44 & 0.22 \\
\hline $\mathrm{Al}$ & 0.16 & 0.13 & 0.31 & 0.10 \\
\hline $\mathrm{Si}$ & 0.50 & 0.50 & 0.73 & 0.30 \\
\hline $\mathrm{Ag}$ & 0.62 & 0.24 & 0.00 & 0.87 \\
\hline $\mathrm{Ca}: \mathrm{P}$ & 2.05 & 2.1589 & 2.2042 & 2.0429 \\
\hline $\mathrm{C}: \mathrm{CaP}$ & 4.56 & 6.0145 & 4.2858 & 4.2646 \\
\hline
\end{tabular}

calcium $9.99 \% \pm 1.11 \%$ and phosphorus $5.34 \% \pm 0.78 \%$ (Fig. 12). The $\mathrm{Ca}: \mathrm{P}$ ratio was $2.20 \pm 0.78$ and $\mathrm{C}: \mathrm{Ca}+\mathrm{P}$ ratio was $4.28 \pm 1.13$. The occurrence of small quantities of cadmium $(\mathrm{Cd})$, copper $(\mathrm{Cu})$, aluminum $(\mathrm{Al})$, and silicon $(\mathrm{Si})$ is noteworthy (Table 2$)$. In the $3^{\text {rd }}$ group - intense bone reorganization - electron microscope examination showed an uneven saturation of the surface with calcium 


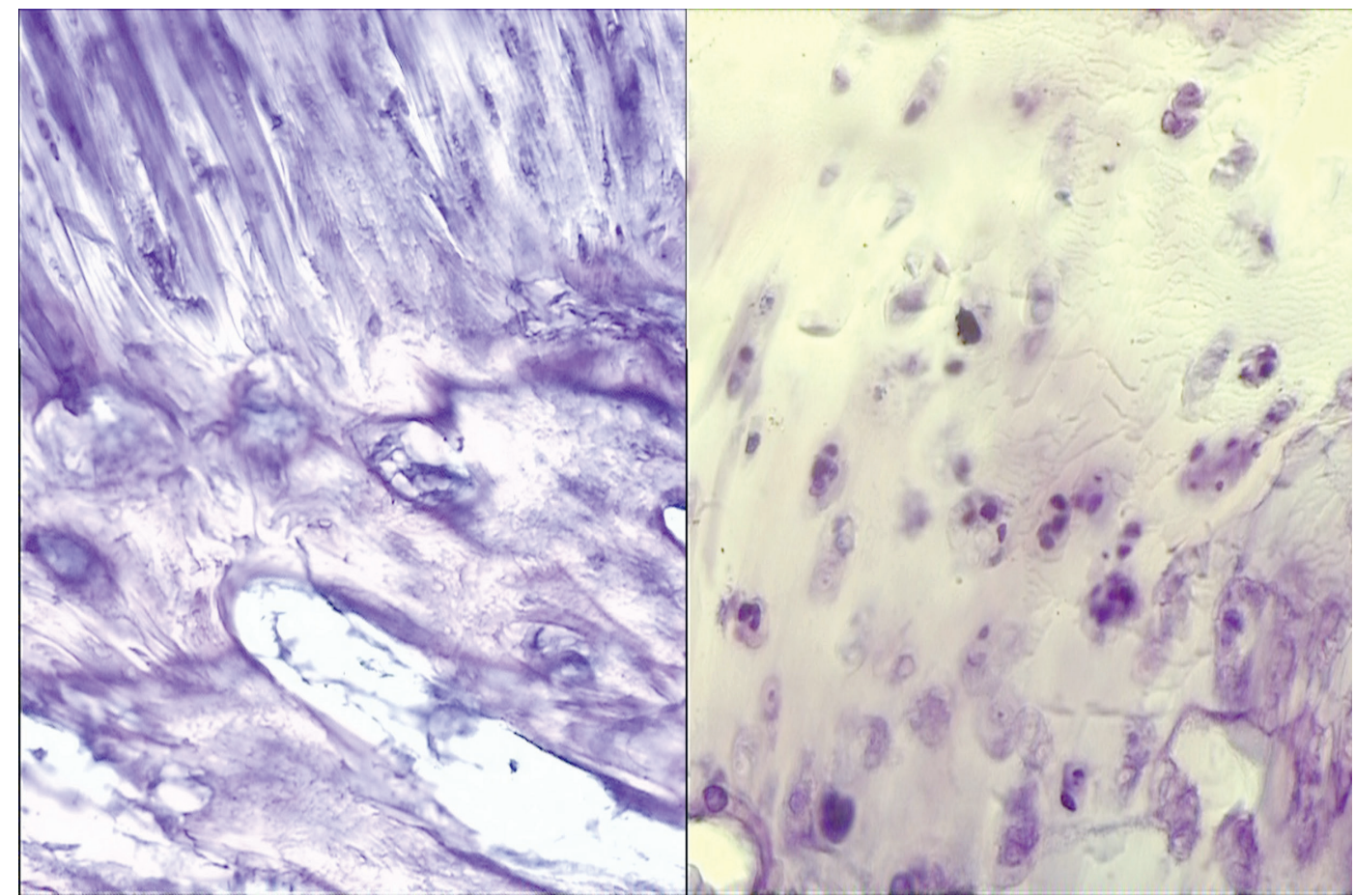

Fig. 11. AK slide (Hist. Ch. 2456/99). Example of spongious bone tissue under electron microscope and distribution of elements on the surface of the slide in group 1 (osteoporosis with a prevalence of coarse-fiber bone tissue and decreased osteogenic activity). Red points correspond to carbon atoms; greenyellow points correspond to calcium and phosphorus ions. Uneven distribution of elements on the surface

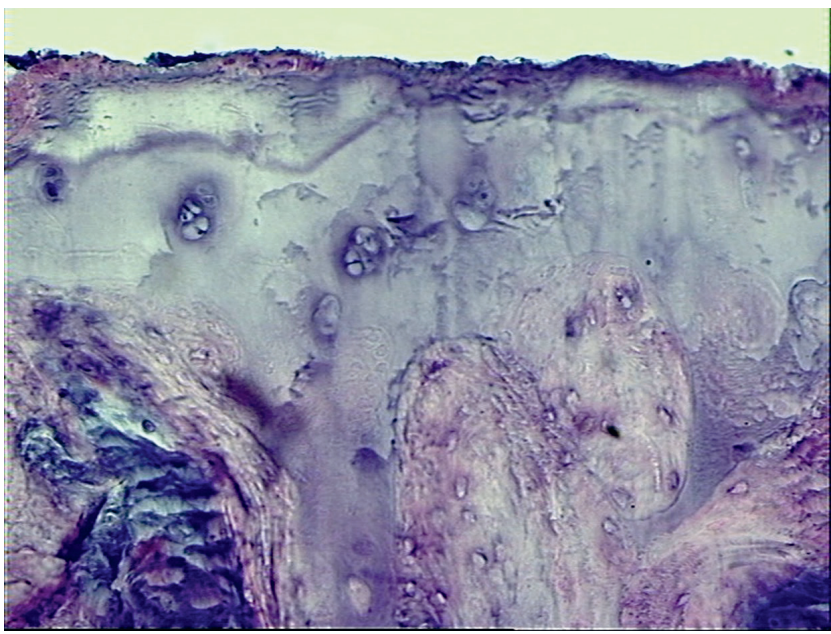

Fig. 12. RM slide (Hist. Ch. 2367/99). Example of spongious bone tissue under electron microscope and distribution of elements on the surface of the slide in group 2 (osteolysis with few centers of osteogenesis). Red points correspond to carbon atoms; green-yellow points correspond to calcium and phosphorus ions. Uneven distribution of elements on the surface

and phosphorus (Fig. 13). The mean carbon content was $52.96 \% \pm 11.34 \%$, calcium $9.40 \% \pm 2.34 \%$ and phosphorus $4.82 \% \pm 1.9 \%$. $\mathrm{Ca}: \mathrm{P}$ was $2.04 \pm 0.59$ and $\mathrm{C}: \mathrm{Ca}+\mathrm{P}$ was $4.26 \pm 1.15$ (Table 2).

Statistical analysis of the data on the mineral composition of the examined bone samples revealed a statistically significant dependence between calcium ( $\mathrm{Ca}$ ) and phosphorus $(\mathrm{P})$, weak dependence between phosphorus $(\mathrm{P})$ and carbon $(\mathrm{C})$ and very weak negative dependence between calcium $(\mathrm{Ca})$ and carbon $(\mathrm{C})$. Oxygen $(\mathrm{O})$ showed a statistically significant negative dependence with carbon $(C)$ and a slightly weaker one with phosphorus (P). The statistically significant negative dependence between $\mathrm{Ca}$ : $\mathrm{P}$ ratio and carbon $(C)$ indicates that this index may potentially be very useful in estimating quantitative and qualitative correlations among the main organic and inorganic components of bone tissue. The $\mathrm{C}: \mathrm{Ca}+\mathrm{P}$ index, reflecting relations between the organic and inorganic components of hydroxyapatite, showed a statistically significant negative dependence with calcium (Ca) and phosphorus (P). It showed no statistically significant dependence with carbon $(C)$, the correlation being 0.0066 (Table 3).

\section{Discussion}

The histological and electron microscope analyses showed degeneration and joint cartilage disappearance in all of the samples examined. It revealed 3 main types of bone tissue changes in the femoral heads: osteoporosis with a prevalence of coarse-fiber bone tissue and decreased osteogenic activity, osteolysis with few centers of osteogenesis, and intensified reorganization of bone tissue. In more than half of the samples, the coarse-fiber bone tissue was replaced by newly formed bone tissue. The observed morphological changes point to ongoing processes of bone resorption and osteogenesis, which indicate a normal homeostasis of bone tissue.

The mineralogical analysis of the bone samples showed an uneven saturation of mineral components within the spongious bone tissue. The indices of the content of organic and inorganic bone components $-\mathrm{Ca}: \mathrm{P}$ and $\mathrm{C}: \mathrm{Ca}+\mathrm{P}$ - were similar across all 3 groups; only bones with intense osteolysis contained less carbon: 4.96-8.13\% less than the osteoporotic and intensely reorganized bone samples. 


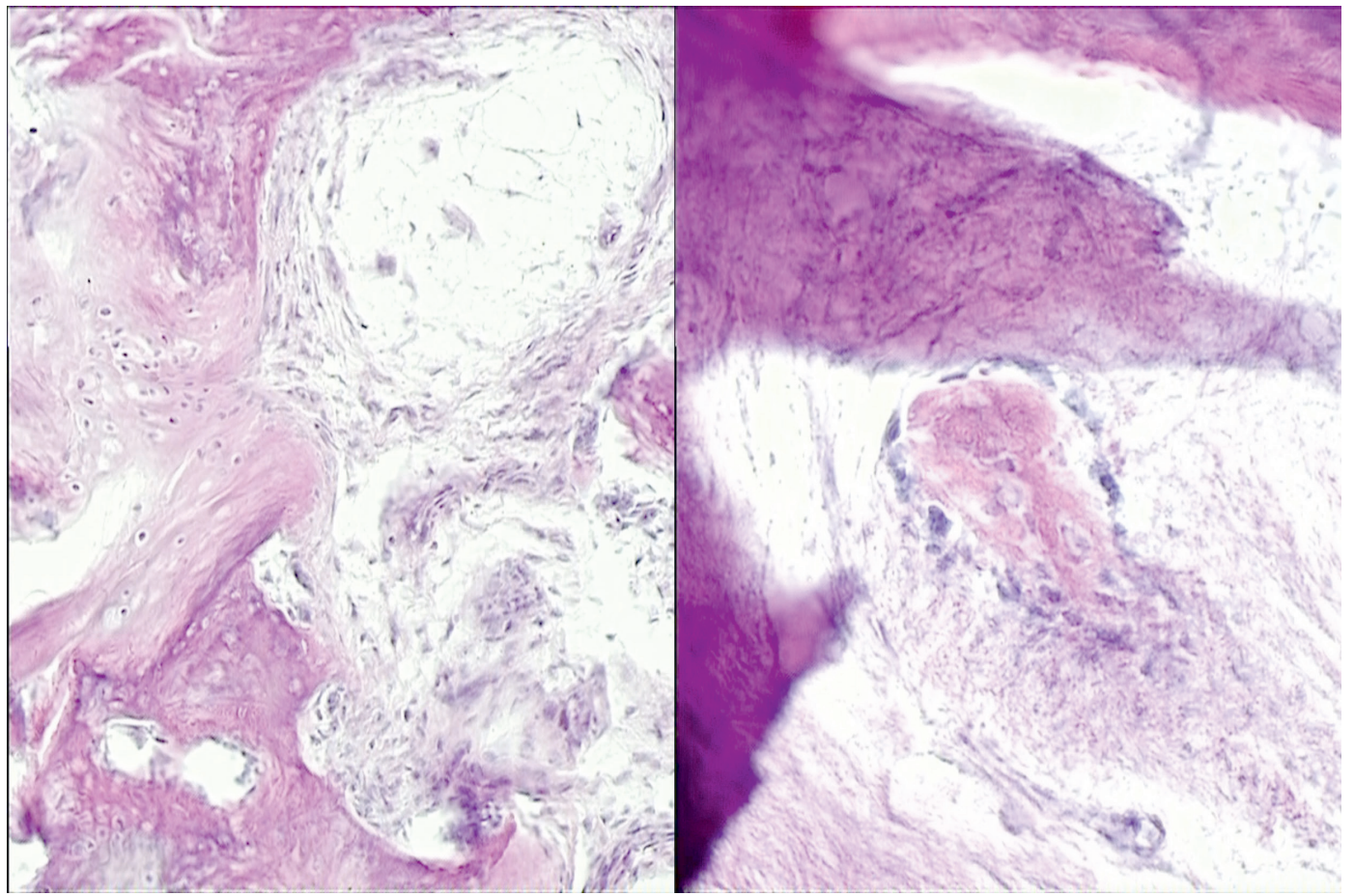

Fig. 13. JZ slide (Hist.

Ch. 1387/99). Example of spongious bone tissue under electron microscope and distribution

of elements on the surface of the slide in group 3 (intensified reorganization of bone tissue). Red points correspond to carbon atoms; green-yellow points correspond to calcium and phosphorus ions. Uneven distribution of elements on the surface

Table 3. Correlation between inorganic and organic components and Ca: P and C: Ca + P ratios in the bone tissue of the studied femoral heads

\begin{tabular}{|c|c|c|c|c|c|c|c|c|}
\hline $\begin{array}{l}\text { Correlation } \\
\text { coefficient }\end{array}$ & $\begin{array}{l}\text { Carbon } \\
\text { (C) }\end{array}$ & $\begin{array}{l}\text { Calcium } \\
\text { (Ca) }\end{array}$ & $\begin{array}{l}\text { Phosphorus } \\
\text { (P) }\end{array}$ & $\begin{array}{l}\text { Oxygen } \\
(\mathrm{O})\end{array}$ & Ca : P ratio & $\begin{array}{c}\mathrm{C}: \mathrm{Ca}+\mathrm{P} \\
\text { ratio }\end{array}$ & $\begin{array}{c}\text { BMD } \\
{\left[\mathrm{g} / \mathrm{cm}^{2}\right]}\end{array}$ & $\begin{array}{c}\mathrm{BMC} \\
{[\mathrm{g}]}\end{array}$ \\
\hline Carbon (C) & 1 & & & & & & & \\
\hline Calcium (Ca) & -0.1547 & 1 & & & & & & \\
\hline Phosphorus (P) & 0.0326 & 0.9526 & 1 & & & & & \\
\hline Oxygen (O) & -0.7800 & -0.4877 & -0.6409 & 1 & & & & \\
\hline Ca $:$ P ratio & -0.7739 & -0.2855 & -0.5194 & 0.8816 & 1 & & & \\
\hline$C: C a+P$ ratio & -0.0066 & -0.7661 & -0.7315 & 0.4977 & 0.2304 & 1 & & \\
\hline $\mathrm{BMD}\left[\mathrm{g} / \mathrm{cm}^{2}\right]$ & 0.3755 & -0.0452 & 0.0934 & -0.3468 & -0.3787 & -0.0527 & 1 & \\
\hline $\mathrm{BMC}[\mathrm{g}]$ & 0.0511 & -0.0348 & 0.0287 & -0.0744 & -0.0767 & 0.3369 & 0.0143 & 1 \\
\hline
\end{tabular}

BMD - bone mineral density; BMC - bone mineral content.

The histological and electron microscope analyses demonstrated that, irrespective of the etiology or advancement of degenerative changes in the hip joint, the processes of bone reorganization take place in the spongious bone tissue of the femoral head. In these processes, apart from the disappearance of bone tissue with a prevalence of fibrous bone tissue formation and osteolysis with centers of osteogenesis, in more than half of the samples examined, processes of transforming coarse-fiber bone tissue into mature lamellate bone tissue were observed. These changes were observed within the femoral head originating from patients at a mean age of 51, even in those with long-term hip joint arthrosis. For this reason, the centers of disappearance and the formation of bone tissue in such patients observed histologically - and sites of denser and sparser arrangement of bone tissue seen on X-ray scans - indicate that bone reorganization of the femoral head takes place not only in the initial period of arthrosis, but also during late-advanced degenerative changes of the hip. Bone reorganization, characterized by the prevalence of osteogenesis processes even in advanced hip arthrosis, suggests that bone tissue has a considerable osteoconductive potential, which creates the proper biological conditions for applying cementless replacements.

The degree of bone tissue mineralization is also important for the mechanical properties of bone. Mineralogical analyses of femoral heads in hip joints with arthrosis were carried out by Bohatyrewicz ${ }^{24}$ and Niedźwiedzki et al. ${ }^{25}$ Niedźwiedzki et al. ${ }^{25}$ limited his studies to the mineral composition of femoral head cartilage in patients with degenerative changes. He found an elevated degree of saturation with mineral components (calcium, phosphorus, magnesium, and potassium) in cartilage with degenerative changes, especially the cartilage covering bone outgrowths. Calcium and phosphorus occurred in the form of "mineral granules". In the cartilage covering bone outgrowths, he also observed changes in ossification. 
Bohatyrewicz, ${ }^{24}$ studying the mechanical properties of bone tissue in the vicinity of the hip joint, found similar values and a positive correlation of calcium content in compact bone tissue with calcium content in spongious bone tissue from the head and neck of the femur. According to the author, the mean calcium content in spongious bone tissue in elderly people was $6.09 \pm 1.22 \mathrm{~mol} / \mathrm{kg}$, while in the compact tissue it was $5.39 \pm 0.99 \mathrm{~mol} / \mathrm{kg}$.

Our mineralogical analysis showed that irrespective of the type of morphological changes, the bone tissue was unevenly saturated with mineral components. In the bone tissue, besides elements typical of bone, small quantities of cadmium, copper, aluminum, and silicon were detected, which might be explained by the effects of diet and environment. ${ }^{9,18,22,26-28}$

According to McLean and Budy, ${ }^{21}$ Kleerekoper et al., ${ }^{22}$ Parfitt et al., ${ }^{23}$ Glimcher, ${ }^{26}$ and Bohatyrewicz, ${ }^{24}$ quantitative analysis of the mineral composition of bone tissue based on calcium-to-phosphorus and carbon-to-calcium plus phosphorus ratios makes it possible to determine the quantity of organic components and hydroxyapatite and enables characteristics of phosphate-calcium metabolism of the bone. In all of the samples of spongious bone tissue examined in this study, irrespective of the ongoing processes of bone tissue reorganization, the calcium-tophosphorus ratio ( $\mathrm{Ca}: \mathrm{P}$ ) was normal, ranging from 2.04 to 2.20, which indicated a normal structure of hydroxyapatite crystals in the bone. The carbon-to-calcium plus phosphorus ratio $(\mathrm{C}: \mathrm{Ca}+\mathrm{P})$ seemed more useful when assessing reorganization of bone tissue. In bone tissue undergoing an intense reorganization, the value of the $\mathrm{C}: \mathrm{Ca}+\mathrm{P}$ ratio ranged from 4.26 to 4.28 , while in the osteoporotic tissue it was 6.01 - indicating disturbances of mineralization, low hydroxyapatite content and thus decreased mechanical resistance of the bone. The usefulness of these indices in assessing the structural and mechanical properties of bone tissue is also supported by the statistically significant negative correlation between carbon and the $\mathrm{Ca}: \mathrm{P}$ ratio $(-0.7739)$ and the $\mathrm{C}: \mathrm{Ca}+\mathrm{P}$ ratio $(-0.7661)$ found in our studies (Table 2). The micromorphometric results indicate that chondrolytic changes take place and that bone resorption and osteogenesis progress simultaneously in both joint cartilage and bone tissue. The processes testify to an intense adaptive reorganization of bone tissue depending on the internal and external factors, including biomechanical condition. Analysis of the histophysiological condition of the femoral heads removed during hip surgery, along with biomechanical studies, may help to determine the osteointegrative capacity of a patient's bones. Progress in this field will not completely eliminate the risk of unfavorable adaptive reorganization of bone tissue, especially tissue surrounding a hip replacement, hence there is a need for further studies on the adaptive reorganization of bone tissue and a search for methods boosting the osteogenic potential of bones and improving the saturation of bone with mineral components. These future studies should make use of biological materials containing pharmacologically-aided osteoprogenitors, e.g., through-cutaneous administration of bone marrow, which is used in clinical practice in cases of healing disturbances after bone fracturing.

\section{Conclusions}

1. Morphological features and mineral composition of spongious bone tissue of the femoral head are disordered in degenerative changes of the hip joint.

2. Continuous bone reorganization of the femoral head takes place not only in the initial period of arthrosis, but also during late-advanced degenerative changes of the hip.

3. We revealed 3 main types of morphological changes to the bone tissue in femoral heads: osteoporosis with a prevalence of coarse-fiber bone tissue and decreased osteogenic activity; osteolysis with few centers of osteogenesis; and intensified reorganization of bone tissue.

4. Irrespective of the etiology or advancement of degenerative changes to the hip joint, saturation of spongious bone tissue with mineral components is uneven.

5. Hydroxyapatite crystals in the bone are normal, but low hydroxyapatite content in the bone increases osteoporotic disorders and decreases the mechanical resistance of the bone.

\section{ORCID iDs}

Mirosław Kulej (D) https://orcid.org/0000-0003-2171-0223 Szymon Łukasz Dragan (D) https://orcid.org/0000-0003-3565-3055 Jan Kuryszko (D) https://orcid.org/0000-0002-2290-2289 Piotr Kuropka (D) https://orcid.org/0000-0002-0682-4743 Wojciech Widuchowski (D https://orcid.org/0000-0002-3684-7823 Szymon Feliks Dragan (D) https://orcid.org/0000-0001-5435-5198

\section{References}

1. Wolff J. The Law of Bone Remodeling. Berlin, West Germany: Springer Verlag; 1986.

2. Frost HM. Skeletal structural adaptations to mechanical usage (SATMU). 1. Redefining Wolff's law: The bone modeling problem. Anat Rec. 1990; 226(4):403-413.

3. Frost HM. Perspectives on artificial joint design. J Long Term EffMed Implants. 1992;2(1):9-35.

4. Frost HM. Wolff's law and bone's structural adaptations to mechanical usage: An overview for clinicians. Angle Orthod. 1994;64(3):175-188.

5. Busse J, Gasteiger W, Tönnis D. Eine neue Methode zur röntgenologischen Beurteilung eines Hüftgelenkes - Der Hüftwert. Arch Orthop TraumaSurg. 1972;72(1):1-9.

6. Owan I, Burr DB, Tuner CH, et al. Mechanotransduction in bone: Osteoblastem are more responsive to fluid forces than mechanical strain. Am J Phys. 1997;273(3 Pt 1):810-815.

7. Fyhrie DP, Kimura JH. Cancellous bone biomechanics. J Biomech. 1999;32(11):1139-1148.

8. Fyhrie DP, Schaffer MB. The adaptation of bone apparent density to applied load. J Biomech. 1995;28(2):135-146.

9. Hert J. Reaction of bone to mechanical stimuli. Part 3. Microstructure of compact bone of rabbit tibia after intermittent loading. Acta Anat (Basel). 1972;82(2):218-230.

10. Lanyon LE. Control of bone architecture by functional load bearing. J Bone Miner Res. 1992;7(Suppl 2):369-375.

11. Minster J. Modelling of viscoelastic deformation of cortical bone tissue. Acta Bioengineering Biomechanics. 2003;5(1):11-20. 
12. O'Connor JA, Lanyon LE, MacFie $\mathrm{H}$. The influence of strain rate on adaptive bone remodeling. J Biomech. 1982;15(10):767-781.

13. Rizzoli R, Bianchi ML, Garabédian M, McKay HA, Moreno LA. Maximizing bone mineral mass gain during growth for the prevention of fractures in the adolescents and the elderly. Bone. 2010;46(2):294-305.

14. Kolundžić R, Trkulja V, Mikolaučić M, Jovanić Kolundžić M, Pavelić SK, Pavelić K. Association of interleukin- 6 and transforming growth factor- $\beta 1$ gene polymorphisms with developmental hip dysplasia and severe adult hip osteoarthritis: A preliminary study. Cytokine. 2011;54(2):125-128.

15. Engh CA, Hooten JP Jr, Zettl-Schaffer KF, et al. Porous-coated total hip replacement. Clin Orthop Relat Res. 1994;298:89-96.

16. Marczyński W. Leczenie zaburzeń zrostu i ubytków tkanki kostnej. Warszawa, Poland: Wydawnictwo Bellona; 1995.

17. Davidson JA. Characteristics of metal and ceramic total hip bearing surfaces and their effect on long-term ultra-high molecular weight polyethylene wear. Clin Orthop Relat Res. 1993;294:361-378.

18. Katz RL, Bourne RB, Rorabeck $\mathrm{CH}, \mathrm{McGee} \mathrm{H}$. Total hip arthroplasty in patients with avascular necrosis of the hip: Follow-up observations on cementless and cemented operations. Clin Orthop Relat Res. 1992;281: 145-151.

19. Lees $\mathrm{S}$, Davidson $\mathrm{CL}$. The role of collagen in the elastic properties of calcified tissues. J Biomech. 1977;10(8):473-486.

20. Beaupré GS, Orr TE, Carter DR. An approach for time-dependent bone modeling and remodeling: Theoretical development. J Orthop Res. 1990;8(5):651-661.
21. McLean FC, Budy AM. The mineral of bones and teeth. In: Radiation, isotopes, and bone. New York, Academic;1964:61-77.

22. Kleerekoper $M$, Peterson EL, Nelson DA, et al. A randomized trial of sodium fluoride as a treatment for postmenopausal osteoporosis. Osteoporos Int. 1991;1(3):155-161.

23. Parfitt AM, Drenzer MK, Glorieux FH, et al. Bone histomorphometry: Standardization of nomenclature, symbols and unit. J Bone Mineral Res. 1987;2(6):595-611.

24. Bohatyrewicz A. Effects of fluoride on bone metabolism and mechanical competence: Clinical observations and experimental studies in rats [in Polish] [habilitation thesis]. Szczecin, Poland:Pomeranian Medical University; 2002

25. Niedźwiedzki T, Pawlikowski M, Kita B.Zmiany mineralogiczne w chrząstce stawu biodrowego u osób ze zmianami zwyrodnieniowymi. Chir Narz Ruchu Ortop Pol. 1987:42:354-356.

26. Glimcher MJ. The nature of mineral component of bone and the mechanism of calcification. In: Avioli LV, Krane FM. Metabolic Bone Disease and Clinically Related Disorders. $2^{\text {nd }}$ ed. Philadelphia, PA:Saunders; 1990:42-56.

27. Kumarasinghe DD, Perilli $\mathrm{E}$, Tsangari $\mathrm{H}$, et al. Critical molecular regulators, histomorphometric indices and their correlations in the trabecular bone in primary hip osteoarthritis. Osteoarthritis Cartilage. 2010;18(10):1337-1344.

28. Power J, Poole KE, van Bezooijen $\mathrm{R}$, et al. Sclerostin and the regulation of bone formation: Effects in hip osteoarthritis and femoral neck fracture. J Bone Miner Res. 2010;25(8):1867-1876. 